\title{
Isolation and characterization of thermotolerant yeasts for the production of second-generation bioethanol
}

\author{
Huynh Xuan Phong ${ }^{1,2,3} \cdot$ Preekamol Klanrit $^{1,4} \cdot$ Ngo Thi Phuong Dung ${ }^{2} \cdot$ Mamoru Yamada $^{5} \cdot$ \\ Pornthap Thanonkeo ${ }^{1,4}$ (D)
}

Received: 23 November 2018 / Accepted: 19 March 2019/Published online: 22 April 2019

(C) Università degli studi di Milano 2019

\begin{abstract}
The purpose of this study was to isolate, identify, and characterize the thermotolerant yeasts for use in high-temperature ethanol fermentation. Thermotolerant yeasts were isolated and screened from soil samples collected from the Mekong Delta, Vietnam, using the enrichment method. Classification and identification of the selected thermotolerant yeasts were performed using matrixassisted laser desorption ionization/time-of-fight mass spectrometry (MALDI-TOF/MS) and nucleotide sequencing of the D1/D2 domain of the 26S rDNA and the internal transcribed spacer (ITS) 1 and 2 regions. The ethanol production by the selected thermotolerant yeast was carried out using pineapple waste hydrolysate (PWH) as feedstock. A total of 174 yeast isolates were obtained from 80 soil samples collected from 13 provinces in the Mekong Delta, Vietnam. Using MALDI-TOF/MS and nucleotide sequencing of the D1/D2 domain and the ITS 1 and 2 regions, six different yeast species were identified, including Meyerozyma caribbica, Saccharomyces cerevisiae, Candida tropicalis, Torulaspora globosa, Pichia manshurica, and Pichia kudriavzevii. Among the isolated thermotolerant yeasts, P. kudriavzevii CM4.2 displayed great potential for high-temperature ethanol fermentation. The maximum ethanol concentration $(36.91 \mathrm{~g} / \mathrm{L})$ and volumetric ethanol productivity $(4.10 \mathrm{~g} / \mathrm{L} \mathrm{h})$ produced at $45^{\circ} \mathrm{C}$ by $P$. kudriavzevii CM4.2 were achieved using PWH containing $103.08 \mathrm{~g} / \mathrm{L}$ of total sugars as a feedstock. These findings clearly demonstrate that the newly isolated thermotolerant yeast $P$. kudriavzevii CM4.2 has a high potential for secondgeneration bioethanol production at high temperature.
\end{abstract}

Keywords Ethanol production · High-temperature fermentation · Pichia kudriavzevii · Pineapple waste $\cdot$ Second-generation bioethanol $\cdot$ Thermotolerant yeasts

Electronic supplementary material The online version of this article (https://doi.org/10.1007/s13213-019-01468-5) contains supplementary material, which is available to authorized users.

Pornthap Thanonkeo

portha@kku.ac.th

1 Department of Biotechnology, Faculty of Technology, Khon Kaen University, Khon Kaen 40002, Thailand

2 Graduate School, Khon Kaen University, Khon Kaen 40002, Thailand

3 Department of Microbial Biotechnology, Biotechnology Research and Development Institute (BiRDi), Can Tho University, Can Tho 900000, Vietnam

4 Fermentation Research Center for Value Added Agricultural Products (FerVAAPs), Khon Kaen University, Khon Kaen 40002, Thailand

5 Department of Biological Chemistry, Faculty of Agriculture, Yamaguchi University, Yamaguchi 753-8515, Japan

\section{Introduction}

Ethanol is one of the most popular sources of alternative energy because it can be mixed with petrol to increase the heat of vaporization and octane number. More than $90 \%$ of ethanol currently used in the fuel market is produced from sugar- or starch-based materials, such as sugarcane, cassava, and corn (Gombert and van Maris 2015), which may compete with and increase the price of these materials used for food for human needs and animal feed (Farrell et al. 2006). Agricultural wastes provide an abundant renewable resource for secondgeneration bioethanol production due to their high sugar content and wide availability without competing with the increasing food demand from food crops (Saini et al. 2015; Aditiya et al. 2016; Rastogi and Shrivastava 2017; Robak and Balcerek 2018; Carrillo-Nieves et al. 2019). Pineapple is an economic crop with a worldwide production of approximately 24.79 million metric tons per year. During the production process, approximately $50 \%$ of the pineapple is discarded as 
wastes, including pineapple peels, cores, stems, and leaves (Ketnawa et al. 2012). Among these, pineapple peel has been shown to be a promising raw material for ethanol production, since it is highly biodegradable and rich in proteins and carbohydrates (Choonut et al. 2014).

High-temperature ethanol fermentation using thermotolerant yeasts offers several advantages including higher yields of saccharification and fermentation products, a decreased energy requirement for product recovery, and a reduction of cooling costs and contamination (Arora et al. 2015). Several yeast species are currently used industrially or may have potential application in ethanol production, such as Saccharomyces cerevisiae, Pichia kudriavzevii, Kluyveromyces marxianus, and Candida shehatae. $S$. cerevisiae is well known as an industrial ethanol producer, with the ability to ferment under both anaerobic and aerobic conditions and accumulate high levels of ethanol (Radecka et al. 2015; Nuanpeng et al. 2016). P. kudriavzevii has been isolated from a variety of niches and is known as a typical thermal- and furfural-tolerant yeast (Kurtzman et al. 2011). It has been widely used in the production of many biological products, such as single-cell protein (Rachamontree et al. 2015), biodiesel (Sankh et al. 2013), D-xylonate (Toivari et al. 2013), and phytase (Hellström et al. 2012). Although there are many reports describing ethanol production using thermotolerant yeasts (Yuangsaard et al. 2013; Charoensopharat et al. 2015; Nuanpeng et al. 2016; Chamnipa et al. 2018), only a few studies have considered the isolation of thermotolerant yeasts for hightemperature ethanol fermentation from the Mekong Delta, Vietnam (Techaparin et al. 2017). In this study, thermotolerant yeasts isolated from soil samples collected from 13 provinces in the Mekong Delta, Vietnam, were isolated, identified, and characterized. The ethanol production efficiency of the selected thermotolerant yeasts at high temperature using pineapple waste hydrolysate $(\mathrm{PWH})$ as a raw material was also investigated.

\section{Materials and methods}

\section{Raw material and yeast strain}

Pineapple wastes (pineapple peels) were collected from the Food Services Center, Khon Kaen University, Thailand. These raw materials were chopped into small pieces, sun dried for 3 days and finally dried in a hot air oven at $80^{\circ} \mathrm{C}$ for $24 \mathrm{~h}$. The resulting raw materials were milled and stored at room temperature prior to use. The PWH was prepared using the method as described by Rattanapoltee and Kaewkannetra (2014). Briefly, $0.5 \%(v / v) \mathrm{H}_{2} \mathrm{SO}_{4}$ solution was added into $200 \mathrm{~g} / \mathrm{L}$ of dried pineapple waste and pre-treated at $121{ }^{\circ} \mathrm{C}$ for $15 \mathrm{~min}$. After hydrolysis, the pellet was filtered and the resulting supernatant (referred to as $\mathrm{PWH}$ ) was collected and kept at $-20{ }^{\circ} \mathrm{C}$. The chemical compositions of the $\mathrm{PWH}$ consisted of $103.08 \mathrm{~g} / \mathrm{L}$ of total sugars, including $41.18 \mathrm{~g} / \mathrm{L}$ of glucose, $46.15 \mathrm{~g} / \mathrm{L}$ of fructose, $4.61 \mathrm{~g} / \mathrm{L}$ of xylose, and $4.46 \mathrm{~g} / \mathrm{L}$ of arabinose. Some minerals, such as nitrogen (686 mg/L), phosphorus $(274 \mathrm{mg} / \mathrm{L})$, magnesium (126 mg/ $\mathrm{L})$, potassium $(4344 \mathrm{mg} / \mathrm{L})$, manganese $(34 \mathrm{mg} / \mathrm{L})$, and zinc $(5 \mathrm{mg} / \mathrm{L})$, and some inhibitors, such as acetic acid $(8.54 \mathrm{~g} / \mathrm{L})$, formic acid $(0.96 \mathrm{~g} / \mathrm{L})$, and furfural $(0.4 \mathrm{mg} / \mathrm{L})$, were also present in the PWH. The thermotolerant yeast $K$. marxianus DBKKU Y-102 (Charoensopharat et al. 2015) was used as a reference strain in this study.

\section{Isolation and characterization of thermotolerant yeasts}

Soil samples from fruit gardens (citrus, jackfruit, rambutan, and mango), agricultural farms (cassava, sweet potato, sugarcane, and pineapple), and sugarcane factories were collected from 13 provinces in the Mekong Delta, Vietnam, including An Giang, Bac Lieu, Ben Tre, Ca Mau, Can Tho, Dong Thap, Hau Giang, Kien Giang, Long An, Soc Trang, Tien Giang, Tra Vinh, and Vinh Long. The thermotolerant yeasts were isolated at $35{ }^{\circ} \mathrm{C}$ using the enrichment method (Yuangsaard et al. 2013). Pure cultures of the isolated yeasts were maintained on yeast malt extract (YM) agar at $4{ }^{\circ} \mathrm{C}$.

The thermo-, ethanol, and acetic acid tolerance of the isolated yeasts were determined using the streak plate and drop plate techniques. For the thermotolerance test, yeasts were grown on YM agar plates containing $4 \%(v / v)$ ethanol and were incubated at $37,40,43$, and $45{ }^{\circ} \mathrm{C}$ for $24 \mathrm{~h}$. For the ethanol tolerance test, yeasts were grown on YM agar plates containing 8, 10, 12, and $14 \%(v / v)$ ethanol. For the acetic acid tolerance test, yeasts were grown on YM agar plates containing 4, 6, 8, and $10 \mathrm{~g} / \mathrm{L}$ acetic acid. Yeast cultures were inoculated onto the agar plates, which were then sealed with plastic wrap and incubated at $35{ }^{\circ} \mathrm{C}$ for $24 \mathrm{~h}$. Yeast growth was monitored and photographed.

\section{Screening and selection of thermotolerant ethanol-fermenting yeasts}

Yeasts with high potential thermotolerance and ethanol fermentation activity screened for at $37^{\circ} \mathrm{C}$ in test tubes containing $10 \mathrm{~mL}$ of $\mathrm{YM}$ broth $(160 \mathrm{~g} / \mathrm{L}$ D-glucose, $\mathrm{pH} 5.0)$ (Nuanpeng et al. 2016). For each isolate, a single yeast colony from a YM agar plate incubated for $18 \mathrm{~h}$ was inoculated into a test tube and cultured on a rotary shaker $(150 \mathrm{rpm})$ at $37^{\circ} \mathrm{C}$. After $60 \mathrm{~h}$ of fermentation, culture broths were withdrawn and centrifuged, and the ethanol concentration in the clear supernatant was determined via gas chromatography (GC) as described by Nuanpeng et al. (2016). The yeast isolates that produced high levels of ethanol were selected, and their carbon utilization was further analyzed using Biolog MicroStation (Biolog Inc., USA). 


\section{Classification and identification of the thermotolerant yeasts}

Morphological analysis of all isolates was performed using the standard method described by Kurtzman et al. (2011). All yeast isolates were classified using whole cell matrixassisted laser desorption ionization/time-of-flight mass spectrometry (MALDI-TOF/MS; Ultraflex, Bruker Daltonics, USA). The obtained spectra were analyzed to create the dendrogram using BioTyper (Bruker Daltonics) (Tani et al. 2015).

To identify the selected thermotolerant yeasts, nucleotide sequencing of the D1/D2 domain of the 26S rDNA was performed using the specific primers NL-1 (5'-GCATATCAATAAGC GGAGGAAAAG-3') and NL-4 (5'-GGTCCGTGTTTCA AGACGG-3') (O'Donnell 1993). Further confirmation of the yeast species was performed by nucleotide sequencing of the internal transcribed spacer (ITS) 1 and 2 regions using the specific primers ITS1 (5'-TCCGTAGGTGAACCTGCGG-3') and ITS4 (5'-TCCTCCGCTTATTGATATGC-3') (White et al. 1990). The nucleotide sequences were determined using an automated Beckman Coulter sequencer (GenomeLab GeXP, USA) and were compared to the type strains in National Center for Biotechnology Information (NCBI). The nucleotide sequences were aligned using CLUSTAL W, and a phylogenetic tree was constructed using the neighbor-joining method with MEGA version 6.0 with a bootstrap number of 1000 (Tamura et al. 2013).

\section{Ethanol production of the selected thermotolerant yeasts using YM medium}

The ethanol fermentation efficiency of the selected thermotolerant yeasts was evaluated in $250-\mathrm{mL}$ flasks using YM medium ( $\mathrm{pH}$ 5.0) containing $160 \mathrm{~g} / \mathrm{L}$ glucose. The yeast inocula were grown in $\mathrm{YM}$ medium at $35^{\circ} \mathrm{C}, 150 \mathrm{rpm}$ for $18 \mathrm{~h}$, and were transferred into $250-\mathrm{mL}$ Erlenmeyer flasks containing $100 \mathrm{~mL}$ of YM medium to an initial cell concentration of $1 \times 10^{7}$ cells $/ \mathrm{mL}$. The flasks were incubated at 37,40 and $45^{\circ} \mathrm{C}$ on a rotary shaker at $100 \mathrm{rpm}$, with samples taken every $12 \mathrm{~h}$ for ethanol and total sugar analyses. The isolate producing the highest ethanol concentration, volumetric ethanol productivity and ethanol yield was selected for further study.

\section{Optimization of ethanol production from PWH by the selected thermotolerant yeast using a statistical experimental design}

The optimization experiments were conducted in $250-\mathrm{mL}$ Erlenmeyer flasks containing $100 \mathrm{~mL}$ of PWH (pH 5.0). The effect of fermentation factors, including $\left(\mathrm{NH}_{4}\right)_{2} \mathrm{SO}_{4}$ (A), $\mathrm{MnSO}_{4} \cdot \mathrm{H}_{2} \mathrm{O}$ (B), $\mathrm{MgSO}_{4} \cdot 7 \mathrm{H}_{2} \mathrm{O}$ (C), $\mathrm{ZnSO}_{4} \cdot 7 \mathrm{H}_{2} \mathrm{O}$ (D), $\mathrm{KH}_{2} \mathrm{PO}_{4}(\mathrm{E})$, yeast extract $(\mathrm{F}), \mathrm{pH}(\mathrm{G})$, and initial cell concentration $(\mathrm{H})$ as the independent variables on the ethanol production of the selected thermotolerant yeast was evaluated using a
Plackett-Burmam design (PBD). Two levels of each independent variable, i.e., $\mathrm{A}(0.05$ and $3.0 \mathrm{~g} / \mathrm{L}), \mathrm{B}(0.02$ and $1.5 \mathrm{~g} / \mathrm{L}), \mathrm{C}$ $(0.05$ and $2.0 \mathrm{~g} / \mathrm{L}), \mathrm{D}(0.02$ and $1.5 \mathrm{~g} / \mathrm{L}), \mathrm{E}(0.05$ and $2.0 \mathrm{~g} / \mathrm{L}), \mathrm{F}$ $(0$ and $6.0 \mathrm{~g} / \mathrm{L}), \mathrm{G}(4.0$ and 6.0$)$, and $\mathrm{H}\left(1 \times 10^{6}\right.$ and $1 \times 10^{8}$ cells/ $\mathrm{mL})$ were tested. The significant variables selected based on the PBD were subsequently evaluated and optimized using response surface methodology (RSM) based on the central composite design $(\mathrm{CCD})$. The ethanol concentration $(P, \mathrm{~g} / \mathrm{L})$ was used as the response function in this study.

\section{Analytical methods and data analysis}

The viable yeast cell number was determined using a hemacytometer and a methylene blue staining technique (Zoecklien et al. 1995). The total sugar concentrations were measured using the phenol sulfuric acid method (Mecozzi 2005). The ethanol concentration was analyzed by GC (Shimadzu GC-14B, Japan) using polyethylene glycol (PEG-20M) packed column with a flame ionization detector. The sugar compositions (glucose, fructose, xylose, and arabinose) and inhibitors (acetic acid, formic acid, and furfural) of the PWH were analyzed using highperformance liquid chromatography (HPLC) (Shimadzu, Japan) equipped with an Aminex HPX-87H column. Sugars were detected using a refractive index detector, while acids and furfural were detected using the UV-VIS detector at the wavelength of $210 \mathrm{~nm}$. Sulfuric acid $\left(\mathrm{H}_{2} \mathrm{SO}_{4}\right)(5 \mathrm{mM})$ was used as a mobile phase at the flow rate of $0.6 \mathrm{~mL} / \mathrm{min}$ at $40{ }^{\circ} \mathrm{C}$. Minerals in the PWH were analyzed using atomic absorption spectroscopy according to the AOAC standard method. Ethanol yield $\left(Y_{p / s}\right.$, $\mathrm{g} / \mathrm{g}$ ) was calculated as the actual ethanol produced and was expressed as $\mathrm{g}$ ethanol per $\mathrm{g}$ sugar utilized. Volumetric ethanol productivity $\left(Q_{p}, \mathrm{~g} / \mathrm{L} \mathrm{h}\right)$ was calculated using the following equation: $Q_{p}=P / t$, where $P$ is the ethanol concentration $(\mathrm{g} / \mathrm{L})$ and $t$ is the fermentation time (h) giving the greatest ethanol concentration. The ethanol fermentation efficiency $(E y, \%)$ was calculated by the following equation: $E y=(Y p / s / 0.511) \times 100$, where $Y p / s$ is the ethanol yield $(\mathrm{g} / \mathrm{g})$, and 0.511 is the theoretical maximum ethanol yield per unit of glucose from glycolytic fermentation $(\mathrm{g} / \mathrm{g})$. The results were expressed as the mean \pm standard deviation (SD) values from three replicates. Statistical analyses were performed using Statgraphics Centurion XV (Statpoint Technologies, Inc., USA). Analysis of variance (ANOVA) was used to evaluate the differences among the treatments using Duncan's multiple range tests (DMRTs).

\section{Results}

\section{Isolation and characterization of thermotolerant yeasts}

A total number of 174 yeast isolates were obtained from 80 soil samples collected in the Mekong Delta, Vietnam. 
Morphological analysis revealed that most colonies had a smooth surface, while some colonies displayed a rough surface with a white or creamy white color. The margins of the colonies were primarily entire, serrated, or lobate. The cell shapes of the yeast isolates varied, e.g., spherical, ovoid, elongated ellipse, and cylinder with the lengths of 3-11 $\mu \mathrm{m}$ and the widths of 2-6 $\mu \mathrm{m}$ (data not shown). All isolates were tested for their tolerance to high temperature stress, and the results showed that all the isolates could grow at $37^{\circ} \mathrm{C}$. At 40 and $43^{\circ} \mathrm{C}, 157(\sim 90 \%)$ and 135 isolates $(\sim 78 \%)$ could grow, respectively, while only 20 isolates $(\sim 12 \%)$ were able to grow at $45{ }^{\circ} \mathrm{C}$. With respect to ethanol stress, 149 isolates $(\sim 86 \%)$ grew well in YM medium containing 10\% $(v / v)$ ethanol. However, only $61(\sim 35 \%)$ and 30 isolates $(\sim 17 \%)$ could grow in YM medium containing 12 and $14 \%(v / v)$ ethanol, respectively. Based on the growth performance of the isolated yeasts at a relatively high temperature of $40{ }^{\circ} \mathrm{C}$ and an ethanol concentration of $12 \%(v / v)$ (Supplementary Fig. 1), 57 isolates of yeast $(\sim 33 \%)$ were chosen for further experiments.

\section{Screening and selection of thermotolerant ethanol fermentative yeasts}

Fifty-seven thermotolerant yeast isolates were evaluated for their ethanol fermentation capability using YM medium containing $160 \mathrm{~g} / \mathrm{L}$ of glucose as the sole carbon source. All of the selected thermotolerant yeasts were able to produce ethanol at $37^{\circ} \mathrm{C}$, with the ethanol concentrations varying from 23.16 to $48.71 \mathrm{~g} / \mathrm{L}$ after $60 \mathrm{~h}$ of fermentation. Only 8 isolates (designated as BL5.1, HG1.1, CM4.2, HG1.2, DT5.3, CT5.3, TG5.3, and ST1.1) produced ethanol at the concentrations higher than $40 \mathrm{~g} / \mathrm{L}$, which were comparable to those of the reference strain, K. marxianus DBKKU Y-102 (44.40 g/L) (data not shown). By using carbon assimilation analysis, it was shown that the isolates HG1.1 and HG1.2 could assimilate several types of carbon sources, including glucose, sucrose, galactose, trehalose, maltose, raffinose, melibiose, and ethanol, while the other six isolates could utilize only glucose, ethanol, glycerol, and N-acetyl-D-glucosamine (Supplementary Table 1).

The growth characteristics of the eight thermotolerant yeast isolates were determined at various temperatures (Fig. 1a). Six isolates, including BL5.1, CM4.2, CT5.3, DT5.3, ST1.1, and TG5.3, could grow at $37,40,43$, and $45^{\circ} \mathrm{C}$, although their growth was lower than that of the reference strain at 43 and $45^{\circ} \mathrm{C}$. HG1.1 and HG1.2 were able to grow at 37 and $40{ }^{\circ} \mathrm{C}$, but their growth was almost inhibited at 43 and $45{ }^{\circ} \mathrm{C}$. With respect to ethanol stress, all of the assayed yeasts could grow in medium containing $8,10,12$, and $14 \%(v / v)$ ethanol. In contrast, the reference strain was able to grow in the medium containing 8,10 , and $12 \%(v / v)$ ethanol, but its growth was completely inhibited in the medium containing $14 \%(v / v)$ ethanol (Fig. 1b). With respect to acetic acid stress, all isolates could grow in the medium containing $4 \mathrm{~g} / \mathrm{L}$ acetic acid. However, only six isolates, including BL5.1, CM4.2, CT5.3, DT5.3, ST1.1, and TG5.3, could grow in the medium containing 6 and $8 \mathrm{~g} / \mathrm{L}$ acetic acid. Interestingly, only one isolate, CM4.2, could grow in the medium containing $10 \mathrm{~g} / \mathrm{L}$ acetic acid. The isolates HG1.1 and HG1.2 and the reference strain could not grow in the medium containing acetic acid at the concentrations higher than $4 \mathrm{~g} / \mathrm{L}$ (Fig. 1c).

\section{Classification and identification of the thermotolerant yeasts}

Based on the whole-cell MALDI-TOF/MS identification, all 174 thermotolerant yeast isolates were classified into six groups, including M. caribbica, S. cerevisiae, C. tropicalis, T. globosa, P. manshurica, and P. kudriavzevii (Supplementary Fig. 2). To confirm this result, further identification of the yeast species by sequencing the D1/D2 domain of the 26S rDNA and the ITS1 and ITS2 regions was conducted. Only 35 isolates, including eight representative isolates from the 6 groups and 27 isolates exhibiting a high tolerance to heat $\left(40^{\circ} \mathrm{C}\right)$, ethanol $(14 \% v / v)$ and acetic acid $(4 \mathrm{~g} / \mathrm{L})$ were used for this confirmation. Phylogenetic analysis of the DNA sequences revealed that the 35 selected isolates clustered into six groups, including M. caribbica, S. cerevisiae, C. tropicalis, T. globosa, P. manshurica, and P. kudriavzevii, which was the same as those observed by the whole-cell MALDI-TOF/MS (Supplementary Fig. 3). Notably, eight isolates that produced a high concentration of ethanol (more than $40 \mathrm{~g} / \mathrm{L}$ ) at high temperatures were identified as two yeast species, P. kudriavzevii (BL5.1, CM4.2, DT5.3, CT5.3, ST1.1, and TG5.3) and S. cerevisiae (HG1.1 and HG1.2).

\section{Ethanol production by the selected thermotolerant yeasts using YM medium}

The production of ethanol at high temperatures by P. kudriavzevii BL5.1, CM4.2, DT5.3, CT5.3, ST1.1, and TG5.3 and S. cerevisiae HG1.1 and HG1.2 using YM medium containing $160 \mathrm{~g} / \mathrm{L}$ glucose was evaluated, and the results are summarized in Table 1. P. kudriavzevii CM4.2 produced the highest ethanol concentration, volumetric ethanol productivity, and ethanol yield with a relatively high fermentation efficiency at 37,40 , and $45^{\circ} \mathrm{C}$ compared to the other isolates and the reference strain. The maximum ethanol concentrations produced by $P$. kudriavzevii CM4.2 at 37,40 , and $45^{\circ} \mathrm{C}$ were $72.47,71.98$, and $47.76 \mathrm{~g} / \mathrm{L}$, which were approximately 26 , 37 , and $27 \%$ greater than that of the reference strain, respectively. Two S. cerevisiae isolates (HG1.1 and HG1.2) produced relatively high levels of ethanol at 37 and $40{ }^{\circ} \mathrm{C}$, but their fermentation activity decreased remarkably at $45^{\circ} \mathrm{C}$. The ethanol concentrations and productivities produced by these two $S$. cerevisiae strains were approximately $55-56 \%$ and $77-$ 
Fig. 1 Growth of $K$. marxianus DBKKU Y-102 (Km),

P. kudriavzevii (BL5.1, CM4.2, CT5.3, DT5.3, ST1.1, and

TG5.3), and S. cerevisiae (HG1.1 and 1.2) on YM agar medium supplemented with: (A) ethanol at a concentration of $4 \% \%(\mathrm{v} / \mathrm{v})$ and incubated at $37^{\circ} \mathrm{C}(\mathrm{a}), 40^{\circ} \mathrm{C}$ (b), $43{ }^{\circ} \mathrm{C}(\mathrm{c})$, and $45^{\circ} \mathrm{C}(\mathrm{d})$; (B) ethanol at a concentration of $8 \%$ (a), $10 \%(b), 12 \%(c)$, and $14 \%(v / v)$ (d) and incubated at $35^{\circ} \mathrm{C}$; and (C) acetic acid at a concentration of $4 \mathrm{~g} / \mathrm{L}$ (a), $6 \mathrm{~g} / \mathrm{L}$ (b), $8 \mathrm{~g} / \mathrm{L}$ (c), and $10 \mathrm{~g} / \mathrm{L}(v / v)(\mathrm{d})$ and incubated at $35^{\circ} \mathrm{C}$ for $24 \mathrm{~h}$
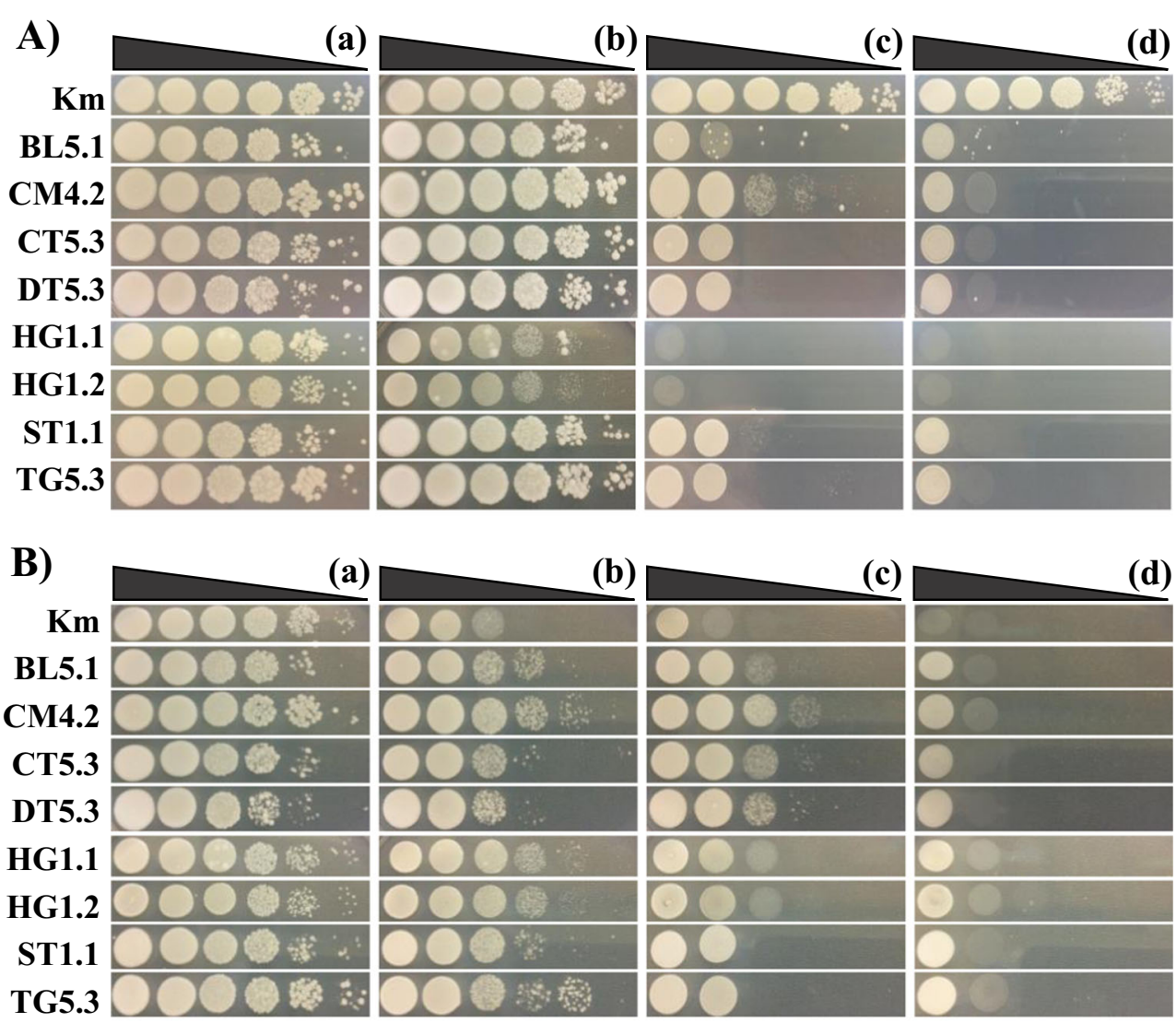

(b)
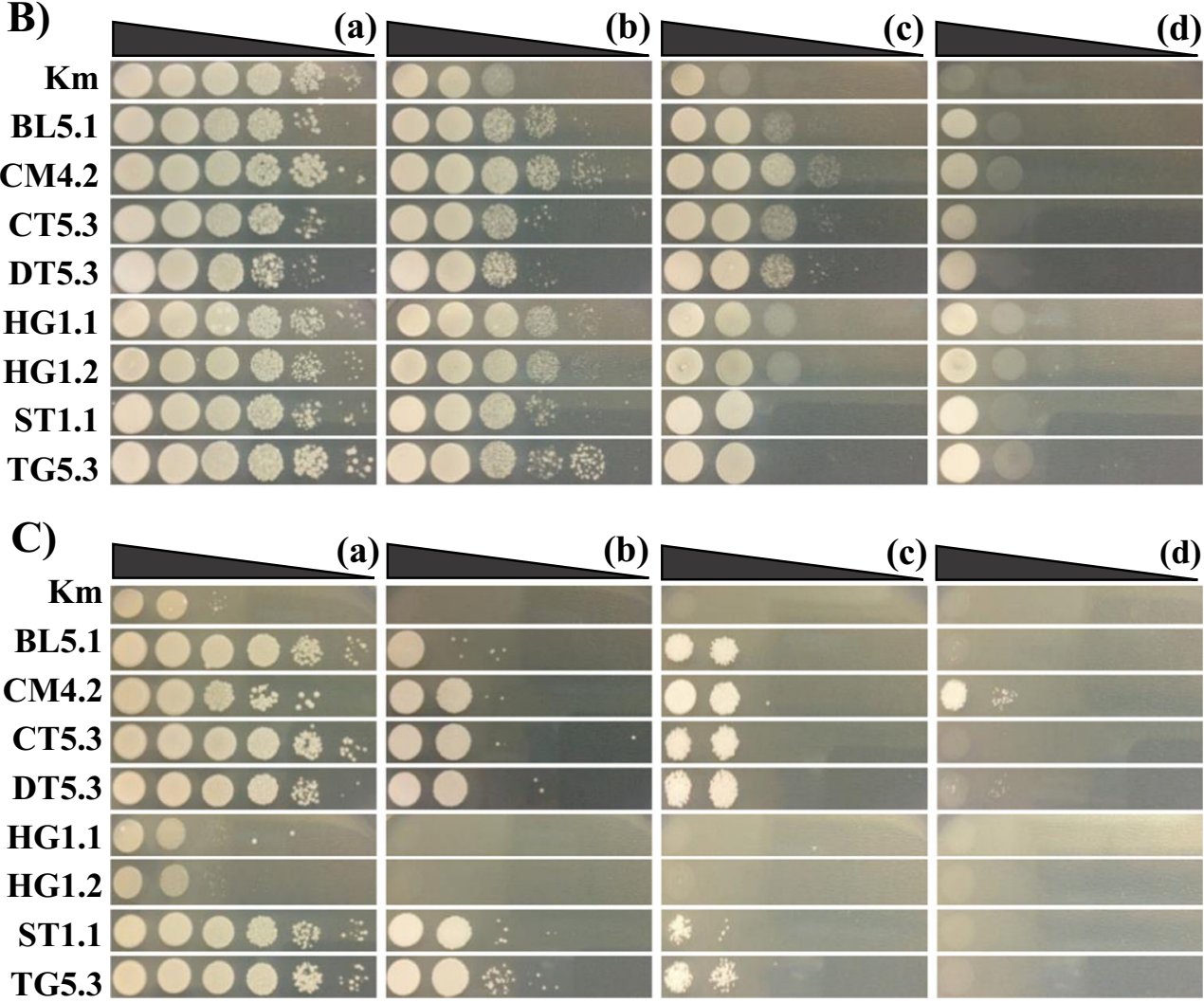

$78 \%$ lower than that of the reference strain at $45^{\circ} \mathrm{C}$, respectively. Based on these findings, P. kudriavzevii CM4.2 was chosen for further study.

\section{Optimization of ethanol production from PWH by $P$. kudriavzevii CM4.2}

The optimum condition for ethanol production by $P$. kudriavzevii CM4.2 using PWH was investigated using a statistical experimental design. The PBD was used to evaluate the significance of each independent variable for ethanol production at a high temperature $\left(45^{\circ} \mathrm{C}\right)$. The experimental design matrices and the response variable from 12 experimental runs are summarized in Supplementary Table 2. The highest ethanol concentration
$(31.40 \mathrm{~g} / \mathrm{L})$ and volumetric ethanol productivity $(2.62 \mathrm{~g} / \mathrm{L} \mathrm{h})$ was achieved from experimental run no. $8\left(3.0 \mathrm{~g} / \mathrm{L}\left(\mathrm{NH}_{4}\right)_{2} \mathrm{SO}_{4}\right.$, $0.02 \mathrm{~g} / \mathrm{L} \mathrm{MnSO}_{4} \cdot \mathrm{H}_{2} \mathrm{O}, 0.05 \mathrm{~g} / \mathrm{L} \mathrm{MgSO}_{4} \cdot 7 \mathrm{H}_{2} \mathrm{O}, 0.02 \mathrm{~g} / \mathrm{L} \mathrm{ZnSO}_{4} \cdot$ $7 \mathrm{H}_{2} \mathrm{O}, 2.0 \mathrm{~g} / \mathrm{L} \mathrm{KH}_{2} \mathrm{PO}_{4}, \mathrm{pH} 6.0$ and $1 \times 10^{8}$ cells $/ \mathrm{mL}$ ), while the lowest concentration $(0.97 \mathrm{~g} / \mathrm{L})$ and volumetric ethanol productivity $(0.08 \mathrm{~g} / \mathrm{L} \mathrm{h})$ of ethanol was achieved from experimental run no.7 (3.0 g/L $\left(\mathrm{NH}_{4}\right)_{2} \mathrm{SO}_{4}, 1.50 \mathrm{~g} / \mathrm{L} \mathrm{MnSO}_{4} \cdot \mathrm{H}_{2} \mathrm{O}, 0.05 \mathrm{~g} / \mathrm{L}$ $\mathrm{MgSO}_{4} \cdot 7 \mathrm{H}_{2} \mathrm{O}, 1.50 \mathrm{~g} / \mathrm{L} \mathrm{ZnSO} \cdot 7 \mathrm{H}_{2} \mathrm{O}, 2.0 \mathrm{~g} / \mathrm{L} \mathrm{KH}_{2} \mathrm{PO}_{4}, 6 \mathrm{~g} / \mathrm{L}$ yeast extract, $\mathrm{pH} 4.0$ and $1 \times 10^{6}$ cells $/ \mathrm{mL}$ ). The reliability of the established model for PBD was tested using ANOVA. As shown in Table 2, the $p$ value of the established model was less than 0.05 (0.0009), indicating that the model was highly significant and could be used to identify the significant variables affecting the ethanol production. According to the $p$ value from ANOVA, four 
Table 1 Ethanol production at 37,40 , and $45^{\circ} \mathrm{C}$ by K. marxianus DBKKU Y-102 (Km), P. kudriavzevii (BL5.1, CM4.2, CT5.3, DT5.3, ST1.1, and TG5.3), and S. cerevisiae (HG1.1 and 1.2) using YM medium containing $160 \mathrm{~g} / \mathrm{L}$ glucose

\begin{tabular}{|c|c|c|c|c|}
\hline \multirow[t]{2}{*}{ Yeast Isolate } & \multicolumn{4}{|c|}{ Parameters $($ mean $\pm \mathrm{SD})$} \\
\hline & $P(\mathrm{~g} / \mathrm{L})$ & $Q_{p}(\mathrm{~g} / \mathrm{L} \mathrm{h})$ & $Y_{p / s}(\mathrm{~g} / \mathrm{g})$ & $E_{y}(\%)$ \\
\hline \multicolumn{5}{|l|}{$37^{\circ} \mathrm{C}$} \\
\hline $\mathrm{Km}$ & $53.54 \pm 1.56 \mathrm{~d}$ & $1.12 \pm 0.04 \mathrm{~d}$ & $0.35 \pm 0.01 \mathrm{c}$ & $69.85 \pm 0.43 d$ \\
\hline BL5.1 & $70.67 \pm 1.78 \mathrm{ab}$ & $1.47 \pm 0.04 \mathrm{a}$ & $0.47 \pm 0.01 \mathrm{ab}$ & $92.20 \pm 1.84 \mathrm{ab}$ \\
\hline CM4.2 & $72.47 \pm 0.13 \mathrm{a}$ & $1.51 \pm 0.01 \mathrm{a}$ & $0.48 \pm 0.00 \mathrm{a}$ & $94.56 \pm 0.18 \mathrm{a}$ \\
\hline CT5.3 & $71.04 \pm 0.86 a b$ & $1.48 \pm 0.02 \mathrm{a}$ & $0.48 \pm 0.01 \mathrm{a}$ & $92.68 \pm 1.11 \mathrm{ab}$ \\
\hline DT5.3 & $68.17 \pm 0.54 c$ & $1.14 \pm 0.01 \mathrm{~cd}$ & $0.46 \pm 0.01 b$ & $88.94 \pm 0.70 \mathrm{c}$ \\
\hline HG1.1 & $71.42 \pm 0.33 \mathrm{ab}$ & $1.49 \pm 0.01 \mathrm{a}$ & $0.48 \pm 0.01 \mathrm{a}$ & $93.18 \pm 0.42 \mathrm{ab}$ \\
\hline HG1.2 & $71.89 \pm 0.78 \mathrm{ab}$ & $1.20 \pm 0.02 b$ & $0.48 \pm 0.01 \mathrm{a}$ & $93.79 \pm 1.02 \mathrm{ab}$ \\
\hline ST1.1 & $72.47 \pm 0.22 \mathrm{a}$ & $1.21 \pm 0.01 \mathrm{~b}$ & $0.48 \pm 0.00 \mathrm{a}$ & $94.54 \pm 0.28 \mathrm{a}$ \\
\hline TG5.3 & $69.78 \pm 0.41 b c$ & $1.17 \pm 0.01 b c$ & $0.47 \pm 0.01 \mathrm{ab}$ & $91.04 \pm 0.54 b c$ \\
\hline \multicolumn{5}{|l|}{$40{ }^{\circ} \mathrm{C}$} \\
\hline $\mathrm{Km}$ & $44.89 \pm 0.64 \mathrm{e}$ & $0.94 \pm 0.01 \mathrm{f}$ & $0.30 \pm 0.00 \mathrm{e}$ & $64.57 \pm 0.83 \mathrm{e}$ \\
\hline BL5.1 & $68.09 \pm 1.71 b c$ & $1.42 \pm 0.03 b c$ & $0.46 \pm 0.02 b c$ & $88.83 \pm 1.52 b c$ \\
\hline CM4.2 & $71.98 \pm 0.90 \mathrm{a}$ & $1.50 \pm 0.01 \mathrm{a}$ & $0.48 \pm 0.01 \mathrm{a}$ & $93.77 \pm 0.99 \mathrm{a}$ \\
\hline CT5.3 & $70.13 \pm 0.52 \mathrm{ab}$ & $1.46 \pm 0.01 \mathrm{ab}$ & $0.47 \pm 0.01 \mathrm{ab}$ & $91.49 \pm 0.67 \mathrm{ab}$ \\
\hline DT5.3 & $67.43 \pm 0.86 b c$ & $1.41 \pm 0.02 \mathrm{bc}$ & $0.45 \pm 0.01 b c$ & $87.98 \pm 1.12 b c$ \\
\hline HG1.1 & $67.20 \pm 1.74 b c$ & $1.40 \pm 0.03 \mathrm{bc}$ & $0.45 \pm 0.02 b c$ & $87.68 \pm 1.26 b c$ \\
\hline HG1.2 & $60.90 \pm 1.23 \mathrm{~d}$ & $1.02 \pm 0.02 \mathrm{e}$ & $0.41 \pm 0.02 \mathrm{~d}$ & $79.45 \pm 1.17 \mathrm{~d}$ \\
\hline ST1.1 & $66.33 \pm 0.05 c$ & $1.11 \pm 0.01 \mathrm{~d}$ & $0.44 \pm 0.01 \mathrm{c}$ & $86.53 \pm 0.07 \mathrm{c}$ \\
\hline TG5.3 & $66.94 \pm 0.01 b c$ & $1.37 \pm 0.02 \mathrm{c}$ & $0.45 \pm 0.01 b c$ & $87.33 \pm 0.01 b c$ \\
\hline \multicolumn{5}{|l|}{$45^{\circ} \mathrm{C}$} \\
\hline $\mathrm{Km}$ & $34.78 \pm 0.57 \mathrm{c}$ & $1.45 \pm 0.02 \mathrm{a}$ & $0.32 \pm 0.01 b$ & $61.87 \pm 0.74 c$ \\
\hline BL5.1 & $32.22 \pm 1.86 \mathrm{c}$ & $0.54 \pm 0.03 \mathrm{~d}$ & $0.32 \pm 0.02 b$ & $63.05 \pm 0.52 \mathrm{c}$ \\
\hline CM4.2 & $47.76 \pm 1.47 \mathrm{a}$ & $1.00 \pm 0.02 b$ & $0.46 \pm 0.01 \mathrm{a}$ & $89.05 \pm 1.21 \mathrm{a}$ \\
\hline СТ5.3 & $40.90 \pm 0.76 b$ & $0.85 \pm 0.01 b c$ & $0.41 \pm 0.01 \mathrm{a}$ & $80.03 \pm 0.99 b$ \\
\hline DT5.3 & $31.24 \pm 1.96 \mathrm{c}$ & $0.87 \pm 0.03 b c$ & $0.31 \pm 0.02 b$ & $61.14 \pm 0.32 c$ \\
\hline HG1.1 & $15.52 \pm 1.81 \mathrm{~d}$ & $0.33 \pm 0.02 \mathrm{e}$ & $0.16 \pm 0.02 c$ & $30.38 \pm 0.21 d$ \\
\hline HG1.2 & $15.21 \pm 1.28 \mathrm{~d}$ & $0.32 \pm 0.03 e$ & $0.15 \pm 0.01 \mathrm{c}$ & $29.84 \pm 0.16 \mathrm{~d}$ \\
\hline ST1.1 & $43.32 \pm 0.55 \mathrm{ab}$ & $0.73 \pm 0.01 \mathrm{c}$ & $0.44 \pm 0.01 \mathrm{a}$ & $84.77 \pm 0.72 \mathrm{ab}$ \\
\hline TG5.3 & $30.16 \pm 1.05 \mathrm{c}$ & $0.50 \pm 0.01 \mathrm{~d}$ & $0.30 \pm 0.02 b$ & $59.01 \pm 1.25 \mathrm{c}$ \\
\hline
\end{tabular}

The mean values with different letters in the same column are significantly different at $p<0.05$ based on DMRT analysis

$P$ ethanol concentration $(\mathrm{g} / \mathrm{L}), Q_{p}$ volumetric ethanol productivity $(\mathrm{g} / \mathrm{L} \mathrm{h}), Y_{p / s}$ ethanol yield $(\mathrm{g} / \mathrm{g}), E_{y}$ fermentation efficiency $(\%)$ independent variables, including $\left(\mathrm{NH}_{4}\right)_{2} \mathrm{SO}_{4}(\mathrm{~A}), \mathrm{MnSO}_{4} \cdot \mathrm{H}_{2} \mathrm{O}$ (B), $\mathrm{pH}(\mathrm{G})$, and initial cell concentration $(\mathrm{H})$ were highly significant parameters affecting the ethanol production from $\mathrm{PWH}$ using P. kudriavzevii CM4.2. The significances of all of the independent variables were further confirmed using a Pareto chart analysis. Based on the $t$ value limit of the experiment, four independent variables $(\mathrm{A}, \mathrm{B}, \mathrm{G}$, and $\mathrm{H})$ were considered significant parameters, similar to the ANOVA results. The variables A, G, and $\mathrm{H}$ showed a positive effect on ethanol production, while variable B exerted a negative effect (Fig. 2). Based on these findings, these four variables were chosen for the optimization experiments.
The optimum condition for ethanol production from PWH using P. kudriavzevii CM4.2 at $45{ }^{\circ} \mathrm{C}$ was determined using RSM based on the CCD. The experimental design matrices and the observed values for the ethanol concentrations and volumetric ethanol productivities are summarized in Supplementary Table 3. The observed ethanol concentrations varied from 9.56 to $32.93 \mathrm{~g} / \mathrm{L}$, while the volumetric ethanol productivities varied from 0.80 to $2.74 \mathrm{~g} / \mathrm{L} \mathrm{h}$. The statistical analysis showed that the established model was highly significant since the $p$ value was less than 0.05 (Table 3 ). Based on the ANOVA, the initial cell concentration (A), $\mathrm{pH}$ (B), 
Table 2 Analysis of variance (ANOVA) for the PlackettBurman design

\begin{tabular}{|c|c|c|c|c|c|c|}
\hline Source & Sum of squares & $d f$ & Mean square & $F$ value & $p$ value $\operatorname{Prob}>F$ & Note \\
\hline Model & 1652.52 & 8 & 206.56 & 138.27 & 0.0009 & Significant \\
\hline $\mathrm{A}-\left(\mathrm{NH}_{4}\right)_{2} \mathrm{SO}_{4}$ & 26.85 & 1 & 26.85 & 17.97 & 0.0240 & Significant \\
\hline $\mathrm{B}-\mathrm{MnSO}_{4} \cdot \mathrm{H}_{2} \mathrm{O}$ & 37.00 & 1 & 37.00 & 24.76 & 0.0156 & Significant \\
\hline $\mathrm{C}-\mathrm{MgSO}_{4} \cdot 7 \mathrm{H}_{2} \mathrm{O}$ & 2.30 & 1 & 2.30 & 1.54 & 0.3031 & \\
\hline $\mathrm{D}-\mathrm{ZnSO}_{4} \cdot 7 \mathrm{H}_{2} \mathrm{O}$ & 5.45 & 1 & 5.45 & 3.65 & 0.1520 & \\
\hline $\mathrm{E}-\mathrm{KH}_{2} \mathrm{PO}_{4}$ & 0.23 & 1 & 0.23 & 0.16 & 0.7196 & \\
\hline F-yeast extract & 0.90 & 1 & 0.90 & 0.60 & 0.4938 & \\
\hline G-pH & 43.66 & 1 & 43.66 & 29.23 & 0.0124 & Significant \\
\hline H-cell & 1536.12 & 1 & 1536.12 & 28.22 & $<0.0001$ & Significant \\
\hline Residual & 4.48 & 3 & 1.49 & & & \\
\hline Cor total & 1657.00 & 11 & & & & \\
\hline Std. dev. & 1.22 & & R-squared & & 0.9973 & \\
\hline C.V. $(\%)$ & 9.20 & & Adj R-squared & & 0.9901 & \\
\hline
\end{tabular}

and their interaction (AB) significantly affected the ethanol production by $P$. kudriavzevii CM4.2 at $45{ }^{\circ} \mathrm{C}$.

The four-factor quadratic polynomial equation derived from the quadratic polynomial regression model used to predict the final ethanol concentration $(P, \mathrm{~g} / \mathrm{L})$ was as follows:

$$
\begin{aligned}
P(\mathrm{~g} / \mathrm{L})= & 31.87+5.24 \mathrm{~A}+3.66 \mathrm{~B} \\
& +0.016 \mathrm{C}-0.18 \mathrm{D}-1.47 \mathrm{AB}+0.085 \mathrm{AC} \\
& +0.16 \mathrm{AD}-0.52 \mathrm{BC}+0.17 \mathrm{BD} \\
& +0.053 \mathrm{CD}-3.10 \mathrm{~A}^{2}-3.20 \mathrm{~B}^{2}-0.42 \mathrm{C}^{2}-0.38 \mathrm{D}^{2}
\end{aligned}
$$

The 3D response surface and contour plots revealed that the most fit model was achieved when the concentrations of $\left(\mathrm{NH}_{4}\right)_{2} \mathrm{SO}_{4}(\mathrm{C})$ and $\mathrm{MnSO}_{4} \cdot \mathrm{H}_{2} \mathrm{O}$ (D) were fixed at 1.55 and
$0.51 \mathrm{~g} / \mathrm{L}$, respectively (Fig. 3). Two parameters, the cell concentration and $\mathrm{pH}$, strongly affected the ethanol production by P. kudriavzevii CM4.2. The maximum ethanol concentration $(32.93 \mathrm{~g} / \mathrm{L})$ and volumetric ethanol productivity $(2.74 \mathrm{~g} / \mathrm{L} \mathrm{h})$ was achieved at the cell concentration of $1.5 \times 10^{8}$ cells $/ \mathrm{mL}$ and the $\mathrm{pH}$ of 5.5.

To verify the optimum values predicted using RSM based on the CCD, repeated experiments were performed to assess ethanol production at $45^{\circ} \mathrm{C}$ by P. kudriavzevii CM4.2 using the initial cell concentration of $2.2 \times 10^{8}$ cells $/ \mathrm{mL}$, the $\mathrm{pH}$ of 5.8, and 1.08 and $0.63 \mathrm{~g} / \mathrm{L}$ of $\left(\mathrm{NH}_{4}\right)_{2} \mathrm{SO}_{4}$ and $\mathrm{MnSO}_{4} \cdot \mathrm{H}_{2} \mathrm{O}$, respectively. As shown in Fig. 4, the maximum ethanol concentration of $36.91 \mathrm{~g} / \mathrm{L}$ was achieved within $9 \mathrm{~h}$ of fermentation. The obtained ethanol yield of $0.49 \mathrm{~g} / \mathrm{g}$ corresponded to the ethanol fermentation efficiency of $95.92 \%$. The observed
Fig. 2 Pareto chart of standardized effects for a Plackett-Burman design of $\left(\mathrm{NH}_{4}\right)_{2} \mathrm{SO}_{4}(\mathrm{~A}), \mathrm{MnSO}_{4} \cdot \mathrm{H}_{2} \mathrm{O}(\mathrm{B})$ $\mathrm{MgSO}_{4} \cdot 7 \mathrm{H}_{2} \mathrm{O}(\mathrm{C}), \mathrm{ZnSO}_{4} \cdot 7 \mathrm{H}_{2} \mathrm{O}$ (D), $\mathrm{KH}_{2} \mathrm{PO}_{4}(\mathrm{E})$, yeast extract (F), $\mathrm{pH}(\mathrm{G})$ and cell concentration (H)

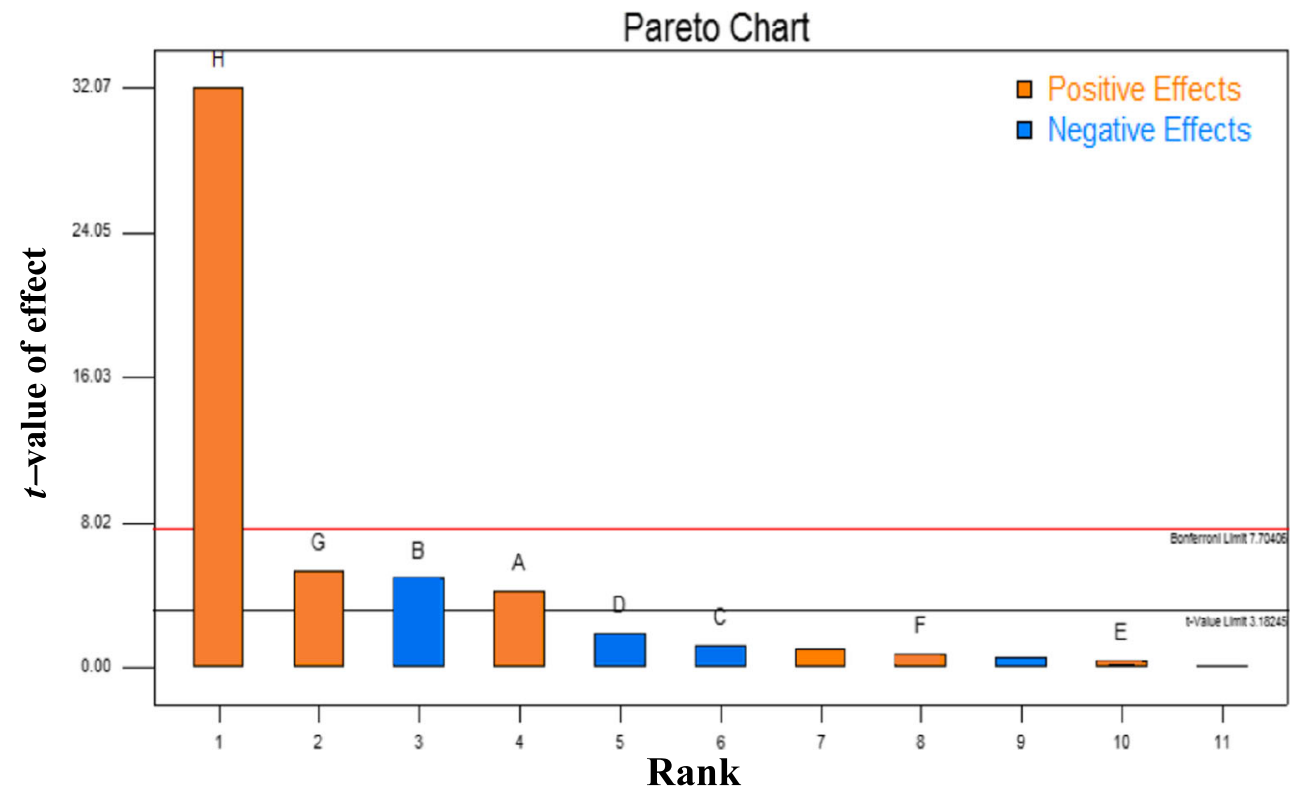


Table 3 Analysis of variance (ANOVA) and the regression analysis results of the CCD on ethanol production using

P. kudriavzevii CM4.2 at $45{ }^{\circ} \mathrm{C}$

\begin{tabular}{|c|c|c|c|c|c|c|}
\hline Source & Sum of squares & $d f$ & Mean square & $F$ value & $p$ value Prob $>F$ & Note \\
\hline Model & 1504.52 & 14 & 107.47 & 38.45 & $<0.0001$ & Significant \\
\hline A & 658.35 & 1 & 658.35 & 235.57 & $<0.0001$ & \\
\hline B & 321.20 & 1 & 321.20 & 114.93 & $<0.0001$ & \\
\hline $\mathrm{C}$ & $6.017 \mathrm{E}-03$ & 1 & $6.017 \mathrm{E}-03$ & $2.153 \mathrm{E}-03$ & 0.9636 & \\
\hline $\mathrm{D}$ & 0.78 & 1 & 0.78 & 0.28 & 0.6039 & \\
\hline $\mathrm{AB}$ & 34.40 & 1 & 34.40 & 12.31 & 0.0032 & \\
\hline $\mathrm{AC}$ & 0.12 & 1 & 0.12 & 0.041 & 0.8416 & \\
\hline $\mathrm{AD}$ & 0.41 & 1 & 0.41 & 0.15 & 0.7072 & \\
\hline $\mathrm{BC}$ & 4.39 & 1 & 4.39 & 1.57 & 0.2293 & \\
\hline $\mathrm{BD}$ & 0.44 & 1 & 0.44 & 0.16 & 0.6964 & \\
\hline $\mathrm{CD}$ & 0.044 & 1 & 0.044 & 0.016 & 0.9017 & \\
\hline $\mathrm{A}^{2}$ & 264.44 & 1 & 264.44 & 94.62 & $<0.0001$ & \\
\hline $\mathrm{B}^{2}$ & 280.43 & 1 & 280.43 & 100.34 & $<0.0001$ & \\
\hline$C^{2}$ & 4.95 & 1 & 4.95 & 1.77 & 0.2029 & \\
\hline $\mathrm{D}^{2}$ & 4.01 & 1 & 4.01 & 1.44 & 0.2494 & \\
\hline Residual & 41.92 & 15 & 2.79 & & & \\
\hline Lack of fit & 37.48 & 10 & 3.75 & 4.22 & 0.0628 & Not significant \\
\hline Pure error & 4.44 & 5 & 0.89 & & & \\
\hline Cor total & 1546.44 & 29 & & & & \\
\hline Std. dev. & 1.67 & & R-squared & & 0.9729 & \\
\hline C.V. $(\%)$ & 6.39 & & Adj R-squared & & 0.9476 & \\
\hline
\end{tabular}

ethanol concentration achieved in this experiment was relatively close to the predicted values, suggesting that the established model was reliable.

\section{Discussion}

The enrichment culture technique has been widely used to isolate useful thermotolerant yeasts for high-temperature ethanol fermentation (Limtong et al. 2007; Yuangsaard et al. 2013; Keo-oudone et al. 2016; Talukder et al. 2016; Choi et al. 2017; Chamnipa et al. 2018). Using this technique, diverse thermotolerant yeasts were successfully isolated from soil samples collected in the Mekong Delta, Vietnam. Several studies have reported the isolation of thermotolerant yeasts from soil samples and obtained several high potential thermotolerant yeasts for high-temperature ethanol fermentation, e.g., P. kudriavzevii PBB511-1 (Kaewkrajay et al. 2014), S. cerevisiae DBKKUY-53 (Nuanpeng et al. 2016), and P. kudriavzevii RZ8-1 (Chamnipa et al. 2018). Although several thermotolerant yeasts have been identified from other sources, e.g., natural fermented products (Talukder et al. 2016), fruits (Keo-oudone et al. 2016), and nuruk (a traditional Korean fermentation starter) (Choi et al. 2017), the present study demonstrated that soil is superior to other sources for isolating thermotolerant yeasts for ethanol production at high temperatures.
The morphological and physiological appearances of the thermotolerant yeasts isolated in the current study were varied depending on the yeast species. However, their characteristics were in good agreement with those described by Kurtzman et al. (2011) and other researchers (Talukder et al. 2016; Techaparin et al. 2017; Chamnipa et al. 2018). The whole-cell MALDI-TOF/MS was used to identify the thermotolerant yeasts (Supplementary Fig. 2). Due to its high sensitivity, cost effectiveness, and rapid processing, this technique has emerged as having a high potential for a number of purposes, such as microbial classification and identification, strain typing, the detection of water- and food-borne pathogens, and the detection of blood and urinary tract pathogens. By either comparing the peptide mass fingerprint (PMF) of an unknown organism with the database PMFs, or by matching the masses of biomarkers of an unknown organism with the proteome database, microbial cells can be identified (Singhal et al. 2015; Tani et al. 2015). In this study, the D1/D2 domain and the ITS regions were also analyzed for microbial identification confirmation at the species levels (Supplementary Fig. 3). Closely related microorganisms, especially those with identical D1/D2 domain DNA sequences, can be differentiated using the ITS1 and ITS2 regions (Chen et al. 2001). Therefore, the classification and identification of yeasts should utilize both sequences.

It should be noted that the thermotolerant yeasts P. kudriavzevii and C. tropicalis were the most abundant yeast species identified in this study, which have been 
Fig. 3 3D response surface plots showing the effect of cell concentration (A), $\mathrm{pH}(\mathrm{B})$, $\left(\mathrm{NH}_{4}\right)_{2} \mathrm{SO}_{4}(\mathrm{C})$, and $\mathrm{MnSO}_{4} \cdot \mathrm{H}_{2} \mathrm{O}$ (D) on the ethanol concentration obtained from $\mathrm{PWH}$ using

P. kudriavzevii CM4.2
Ethanol

32.93

9.56

$\mathrm{X} 1=\mathrm{A}:$ Cell conc $\mathrm{X} 2=\mathrm{B}: \mathrm{pH}$

Actual Factors $\mathrm{C}:(\mathrm{NH} 4) 2 \mathrm{SO} 4=1.55$ $\mathrm{D}: \mathrm{MnSO} 4=0.51$
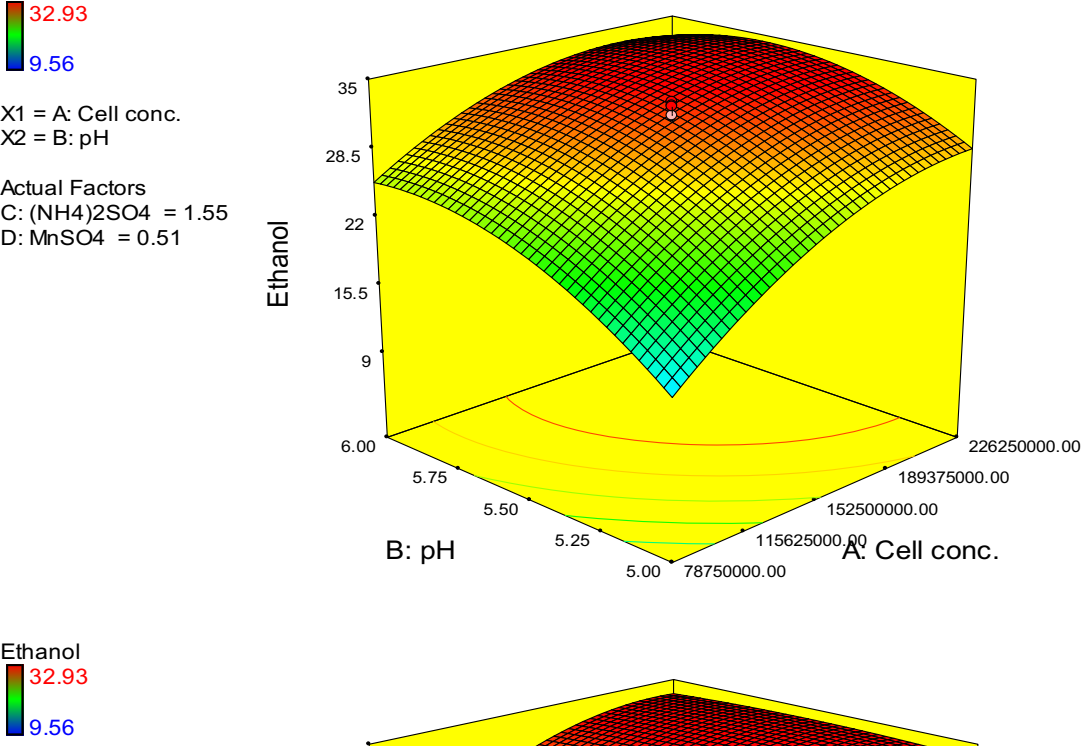

$\mathrm{X} 1=\mathrm{A}:$ Cell conc $\mathrm{X} 2=\mathrm{D}: \mathrm{MnSO} 4$

Actual Factors $\mathrm{B}: \mathrm{pH}=5.50$ $\mathrm{C}:(\mathrm{NH} 4) 2 \mathrm{SO} 4=1.55$

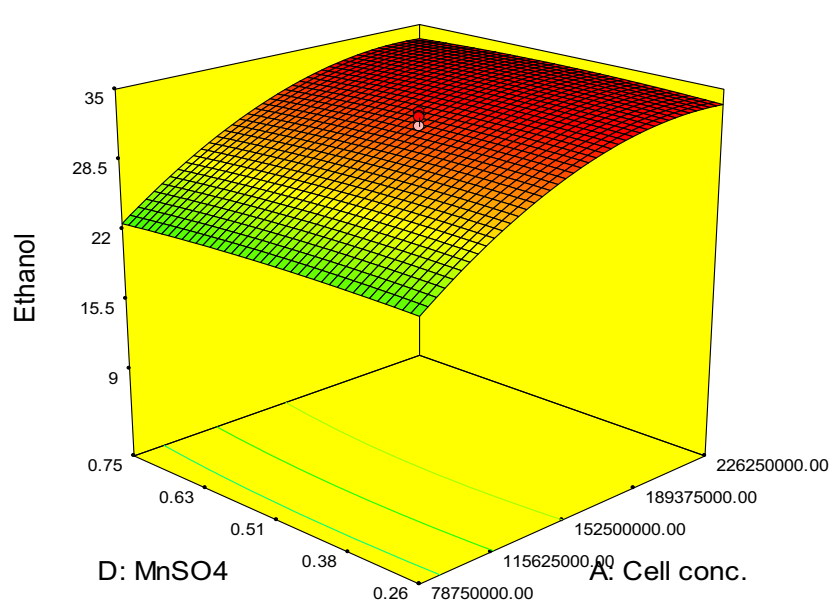

$\mathrm{X} 1=\mathrm{B}: \mathrm{pH}$ $\mathrm{X} 2=\mathrm{C}:(\mathrm{NH} 4) 2 \mathrm{SO} 4$

Actual Factors

$\mathrm{A}:$ Cell conc. $=152500000.00$ $\mathrm{D}: \mathrm{MnSO} 4=0.51$

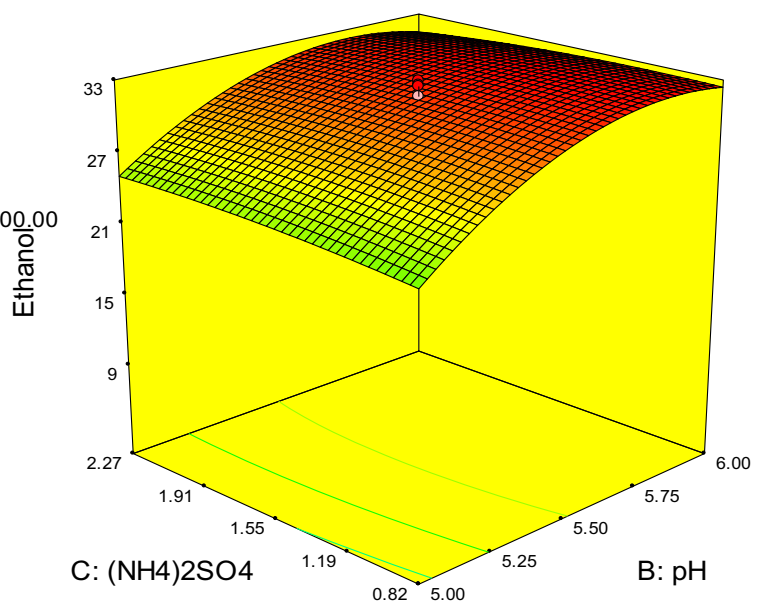

isolated from various sources, such as soil (Yuangsaard et al. 2013; Chamnipa et al. 2018), herbivore feces (Lorliam et al. 2013), fermented cocoa (Hamdouche et al. 2015), and naturally fermented products (Talukder et al. 2016). P. kudriavzevii has been reported to be a thermotolerant yeast with a high potential for ethanol production at high temperatures using cassava starch hydrolysate (Kaewkrajay et al. 2014) and sugarcane bagasse hydrolysate (Chamnipa et al. 2018). S. cerevisiae and T. globosa are recognized as thermotolerant yeasts with a high potential for high-temperature ethanol production that can be isolated from soil (Nuanpeng et al. 2016; 
Techaparin et al. 2017; Tolieng et al. 2018), sugarcane juices, sediments from sugar process, sugar-rich materials, and fruits (Phong et al. 2016). P. manshurica (P. galeiformis) has been reported to be a common spoilage yeast species in wines (Saez et al. 2011), although it displayed great potential for acid and ester production in vinegar (Zhang et al. 2017) as well as ethanol production from glucose (Tolieng et al. 2018). M. caribbica is recognized as a nontoxic yeast that has been used to produce the alcoholic beverage tequila in Mexico (Saucedo-Luna et al. 2011).

Among the isolated thermotolerant yeasts, $P$. kudriavzevii CM4.2 displayed great potential for ethanol production at high temperatures, growing at a relatively high temperature of $45^{\circ} \mathrm{C}$, an ethanol concentration of $14 \%(v / v)$ and an acetic acid concentration of $10 \mathrm{~g} / \mathrm{L}$ (Fig. 1). As shown in Table 1, the maximum ethanol concentrations produced by this strain using $160 \mathrm{~g} / \mathrm{L}$ of glucose were $72.47,71.98$, and $47.76 \mathrm{~g} / \mathrm{L}$ at 37,40 , and $45^{\circ} \mathrm{C}$, respectively, which were higher than those reported by Kaewkrajay et al. (2014) and Chamnipa et al. (2018). When PWH containing $103.08 \mathrm{~g} / \mathrm{L}$ of total sugars was used as a raw material for ethanol production by P. kudriavzevii CM4.2 at $45{ }^{\circ} \mathrm{C}, 36.91 \mathrm{~g} / \mathrm{L}$ of ethanol was achieved under the optimum fermentation condition (Fig. 4).

Several factors influence the growth and ethanol production by yeast, such as the carbon and nitrogen source, $\mathrm{pH}$, incubation temperature, initial yeast cell concentration, and trace elements (Kaewkrajay et al. 2014; Nuanpeng et al. 2016; Techaparin et al. 2017; Chamnipa et al. 2018). To screen the significant factors affecting P. kudriavzevii CM4.2 growth and ethanol production at $45^{\circ} \mathrm{C}$ using PWH, PBD was employed in this study. This experimental design is recognized as an efficient screening method to identify the important factors using as few experimental runs as possible compared with so-called one factor at a time experiments (Khuri and Mukhopadhyay 2010). As shown in the current study, four independent variables, including $\left(\mathrm{NH}_{4}\right)_{2} \mathrm{SO}_{4}$, $\mathrm{MnSO}_{4} \cdot \mathrm{H}_{2} \mathrm{O}, \mathrm{pH}$ and initial cell concentration were identified as the major factors influencing the P. kudriavzevii CM4.2 growth and ethanol production from PWH (Table 2). Yeast cell concentration is one of the important fermentation parameters influencing the sugar utilization rate and fermentation efficiency. Previous studies demonstrated that higher initial cell concentrations enhanced the rate and fermentation efficiency for ethanol production from alkali-treated cotton stalks using $P$. kudriavzevii HOP-1 (Kaur et al. 2012), Jerusalem artichoke tubers using K. marxianus DBKKU Y-102 (Charoensopharat et al. 2015), and sweet sorghum juice using $S$. cerevisiae KKU-VN8 (Techaparin et al. 2017). The $\mathrm{pH}$ value is known as an important factor that directly affects yeast growth and ethanol production. The optimum $\mathrm{pH}$ for yeast growth and ethanol production depends on several factors, such as the growth conditions, the yeast species and the raw materials, and in general the optimum $\mathrm{pH}$ ranges from 4.0-6.0. In this study, the optimum $\mathrm{pH}$ for ethanol production from PWH by P. kudriavzevii CM4.2 was 5.8, which was in good agreement with those values reported by Nuanpeng et al. (2016) and Techaparin et al. (2017) using sweet sorghum juice as a feedstock.

Yeast growth and ethanol production also depend on the nitrogen source because it is essential for the synthesis of structural and functional proteins involved in yeast growth and metabolism. Among the various nitrogen sources, inorganic nitrogen, such as urea and $\left(\mathrm{NH}_{4}\right)_{2} \mathrm{SO}_{4}$ have been shown to be suitable for ethanol production (Nuanpeng et al. 2016). In this study, supplementation of $\left(\mathrm{NH}_{4}\right)_{2} \mathrm{SO}_{4}$ enhanced ethanol production from PWH by P. kudriavzevii CM4.2. This result was in good agreement with those reported by Limtong et al. (2007) using sugarcane juice and Techaparin et al. (2017) using sweet sorghum juice as a feedstock. Trace elements play important roles in yeast growth and ethanol production by serving as a regulator of many important
Fig. 4 Time course of ethanol production from $\mathrm{PWH}$ at $45^{\circ} \mathrm{C}$ using P. kudriavzevii CM4.2 under the optimum conditions. Symbols: (filled diamonds) ethanol; (empty diamonds) sugars; (filled squares) glucose; (empty squares) fructose and xylose; and (circles) arabinose

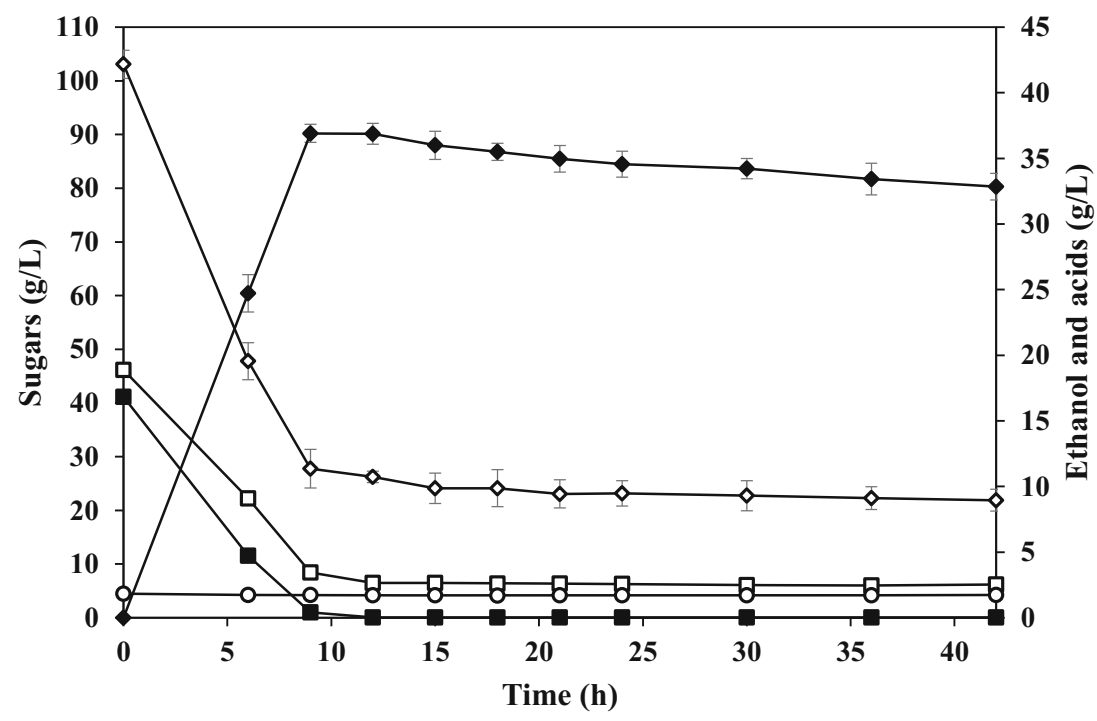


enzymes in microbial cells. Several trace elements have been used to promote the production of ethanol from microbial cells, such as zinc $\left(\mathrm{Zn}^{2+}\right)$, magnesium $\left(\mathrm{Mg}^{2+}\right)$, and manganese $\left(\mathrm{Mn}^{2+}\right)$ (Faga et al. 2010; Deesuth et al. 2012). It should be noted that in this study a number of assayed factors, including yeast extract, $\mathrm{MgSO}_{4} \cdot 7 \mathrm{H}_{2} \mathrm{O}, \mathrm{ZnSO}_{4} \cdot 7 \mathrm{H}_{2} \mathrm{O}$, and $\mathrm{KH}_{2} \mathrm{PO}_{4}$, had no significant effect on the ethanol production by P. kudriavzevii CM4.2, similar with those reported by Rani et al. (2010) and Izmirlioglu and Demirci 2015). One possible reason is that the PWH contains a sufficient amount of organic nitrogen source and trace elements, particularly magnesium, zinc, and potassium. With respect to magnesium, it can decrease the plasma membrane permeability and protect the yeast cells from heat and ethanol stress during ethanol fermentation (Birch and Walker 2000), but it did not promote ethanol production at $45^{\circ} \mathrm{C}$ by $P$. kudriavzevii CM4.2. This finding was in good agreement with a report by Techaparin et al. (2017), who used sweet sorghum juice as a feedstock. In addition, Limtong et al. (2007) and Yuangsaard et al. (2013) also observed that $\mathrm{MgSO}_{4} \cdot 7 \mathrm{H}_{2} \mathrm{O}$ and $\mathrm{KH}_{2} \mathrm{PO}_{4}$ did not improve the ethanol production efficiency of K. marxianus DMKU 3-1042 using sugarcane juice and of $P$. kudriavzevii DMKU 3-ET15 using cassava starch hydrolysate as a feedstock, respectively.

\section{Conclusions}

Diverse yeast species, including $M$. caribbica, S. cerevisiae, C. tropicalis, T. globosa, P. manshurica, and P. kudriavzevii were isolated from soil samples in the Mekong Delta, Vietnam. Among these isolated yeasts, a newly identified thermotolerant yeast strain, P. kudriavzevii CM4.2, displayed great potential for high-temperature ethanol fermentation. This strain could tolerate both high temperatures and ethanol concentrations. Furthermore, it was also highly resistant to high concentrations of acetic acid, making this thermotolerant yeast a very useful organism for ethanol production at high temperatures using lignocellulosic hydrolysate as a feedstock. The maximum ethanol concentration $(36.91 \mathrm{~g} / \mathrm{L})$ produced at $45^{\circ} \mathrm{C}$ by P. kudriavzevii CM4.2 using PWH as substrate was achieved in this study. Thus, pineapple waste has a high potential to be used as feedstock for ethanol production at high temperature.

Acknowledgments The authors thank the Faculty of Technology, Khon Kaen University, for providing the Scholarship to Phong HX. A portion of this work was supported by the Graduate School, Khon Kaen University, Ministry of Science and Technology of Vietnam (the project contract no. 09/2014/HĐ-NĐT), Japan Society for the Promotion of Science (JSPS), and the international collaboration research project Core-to-Core Program (CCP). The authors thank Prof. Akio Tani for assistance with the MALDI-TOF/MS analysis.

Funding This study was funded by the Ministry of Science and Technology of Vietnam (the project contract no. 09/2014/HĐ-NĐT).

\section{Compliance with ethical standards}

Conflict of interest The authors declare that they have no conflict of interest.

Ethical approval This article does not contain any studies with human participants or animals performed by any of the authors.

Informed consent Informed consent was obtained from all individual participants included in the study.

\section{References}

Aditiya HB, Chong WT, Mahlia TMI, Sebayang AH, Berawi MA, Nur H (2016) Second generation bioethanol potential from selected Malaysia's biodiversity biomasses: a review. Waste Manag 47(Pt A):46-61

Arora R, Behera S, Kumar S (2015) Bioprospecting thermophilic/ thermotolerant microbes for production of lignocellulosic ethanol: a future perspective. Renew Sust Energ Rev 51:699-717

Birch RM, Walker GM (2000) Influence of magnesium ions on heat shock and ethanol stress responses of Saccharomyces cerevisiae. Enzym Microb Technol 26:678-687

Carrillo-Nieves D, Alanís MJR, de la Cruz Quiroz R, Ruiz HA, Lqbal HMN, Parra-Saldívar R (2019) Current status and future trends of bioethanol production from agro-industrial wastes in Mexico. Renew Sust Energ Rev 102:63-74

Chamnipa N, Thanonkeo S, Klanrit P, Thanonkeo P (2018) The potential of the newly isolated thermotolerant yeast Pichia kudriavzevii RZ81 for high-temperature ethanol production. Braz J Microbiol 49: 378-391

Charoensopharat K, Thanonkeo P, Thanonkeo S, Yamada M (2015) Ethanol production from Jerusalem artichoke tubers at high temperature by newly isolated thermotolerant inulin-utilizing yeast Kluyveromyces marxianus using consolidated bioprocessing. Anton van Leeuwenhoek 108:173-190

Chen YC, Eisner JD, Kattar MM, Rassoulian-Barrett SL, Lafe K, Bui U, Limaye AP, Cookson BT (2001) Polymorphic internal transcribed spacer region 1 DNA sequences identify medically important yeasts. J Clin Microbiol 39:4042-4051

Choi DH, Park EH, Kim MD (2017) Isolation of thermotolerant yeast Pichia kudriavzevii from nuruk. Food Sci Biotechnol 26:1357-1362

Choonut A, Saejong M, Sangkharak K (2014) The production of ethanol and hydrogen from pineapple peel by Saccharomyces cerevisiae and Enterobacter aerogenes. Energy Procedia 52:242-249

Deesuth O, Laopaiboon P, Jaisil P, Laopaiboon L (2012) Optimization of nitrogen and metal ions supplementation for very high gravity bioethanol fermentation from sweet sorghum juice using an orthogonal array design. Energies 5:3178-3197

Faga BA, Wilkins MR, Banat IM (2010) Ethanol production through simultaneous saccharification and fermentation of switchgrass using Saccharomyces cerevisiae D5A and thermotolerant Kluyveromyces marxianus IMB strains. Bioresour Technol 101:2273-2279

Farrell AE, Plevin RJ, Turner BT, Jones AD, O'Hare M, Kammen DM (2006) Ethanol can contribute to energy and environmental goals. Science 311:506-508

Gombert AK, van Maris AJA (2015) Improving conversion yield of fermentable sugars into fuel ethanol in 1st generation yeast-based production processes. Curr Opin Biotechnol 33:81-86

Hamdouche Y, Guehi T, Durand N, Kedjebo KBD, Montet D, Meile JC (2015) Dynamics of microbial ecology during cocoa fermentation and drying: towards the identification of molecular markers. Food Control 48:117-122 
Hellström AM, Almgren A, Carlsson NG, Svanberg U, Andlid TA (2012) Degradation of phytate by Pichia kudriavzevii TY13 and Hanseniaspora guilliermondii TY14 in Tanzanian togwa. Int $\mathrm{J}$ Food Microbiol 153:73-77

Izmirlioglu G, Demirci A (2015) Enhanced bio-ethanol production from industrial potato waste by statistical medium optimization. Int J Mol Sci 16:24490-24505

Kaewkrajay C, Dethoup T, Limtong S (2014) Ethanol production from cassava using a newly isolated thermotolerant yeast strain. ScienceAsia 40:268-277

Kaur U, Oberoi HS, Bhargav VK, Sharma-Shivappa R, Dhaliwal SS (2012) Ethanol production from alkali- and ozone-treated cotton stalks using thermotolerant Pichia kudriavzevii HOP-1. Ind Crop Prod 37:219-226

Keo-oudone C, Nitiyon S, Sotitham P, Tani A, Lertwattanasakul N, Yuangsaard N, Bounphanmy S, Limtong S, Yamada M (2016) Isolation and characterization of thermotolerant ethanol-fermenting yeasts from Laos and application of whole-cell matrix-assisted laser desorption/ionization time-of-flight mass spectrometry (MALDITOF/MS) analysis for their quick identification. Afr J Biotechnol 15:153-164

Ketnawa S, Chaiwut P, Rawdkuen S (2012) Pineapple wastes: a potential source for bromelain extraction. Food Bioprod Process 90:385-391

Khuri AI, Mukhopadhyay S (2010) Response surface methodology. Wiley Interdiscip Rev Comput Stat 2:128-149

Kurtzman CP, Fell JW, Boekhout T, Robert V (2011) Methods for isolation, phenotypic characterization and maintenance of yeasts. In: Kurtzman CP, Fell JW, Boekhout T (eds) The yeasts, a taxonomic study, 5th edn. Elsevier B.V, San Diego, pp 87-110

Limtong S, Sringiew C, Yongmanitchai W (2007) Production of fuel ethanol at high temperature from sugar cane juice by a newly isolated Kluyveromyces marxianus. Bioresour Technol 98:3367-3374

Lorliam W, Akaracharanya A, Jindamorakot S, Suwannarangsee S, Tanasupawat S (2013) Characterization of xylose-utilizing yeasts isolated from herbivore faeces in Thailand. ScienceAsia 39:26-35

Mecozzi M (2005) Estimation of total carbohydrate amount in environmental samples by the phenol-sulphuric acid method assisted by multivariate calibration. Chemom Intell Lab Syst 79:84-90

Nuanpeng S, Thanonkeo S, Yamada M, Thanonkeo P (2016) Ethanol production from sweet sorghum juice at high temperatures using a newly isolated thermotolerant yeast Saccharomyces cerevisiae DBKKU Y-53. Energies 9:253

O'Donnell K (1993) Fusarium and its near relatives. In: Reynolds DR, Taylor JW (eds) The fungal holomorph: mitotic, meiotic and pleomorphic speciation in fungal systematics. CAB International, Wallingford, pp 225-233

Phong HX, Giang NTC, Nitiyon S, Yamada M, Thanonkeo P, Dung NTP (2016) Ethanol production from molasses at high temperature by thermotolerant yeasts isolated from cocoa. Can Tho Univ J Sci 3: $32-37$

Rachamontree P, Phusantisampan T, Woravutthikul N, Pornwongthong P, Sriariyanun M (2015) Selection of Pichia kudriavzevii strain for the production of single-cell protein from cassava processing waste. Int J Biol Biomol Agric Food Biotechnol Eng 9:481-485

Radecka D, Mukherjee V, Mateo RQ, Stojiljkovic M, Foulquié-Moreno MR, Thevelein JM (2015) Looking beyond Saccharomyces: the potential of non-conventional yeast species for desirable traits in bioethanol fermentation. FEMS Yeast Res 15:fov053

Rani P, Sharma S, Garg FC, Raj K, Wati L (2010) Ethanol production from potato flour by Saccharomyces cerevisiae. Indian J Sci Technol 3:733-736

Rastogi M, Shrivastava S (2017) Recent advances in second generation bioethanol production: an insight to pretreatment, saccharification and fermentation processes. Renew Sust Energ Rev 80:330-340
Rattanapoltee P, Kaewkannetra P (2014) Utilization of agricultural residues of pineapple peels and sugarcane bagasse as cost-saving raw materials in Scenedesmus acutus for lipid accumulation and biodiesel production. Appl Biochem Biotechnol 173:1495-1510

Robak K, Balcerek M (2018) Review of second generation bioethanol production from residual biomass. Food Technol Biotechnol 56: 174-187

Saez JS, Lopes CA, Kirs VE, Sangorrín M (2011) Production of volatile phenols by Pichia manshurica and Pichia membranifaciens isolated from spoiled wines and cellar environment in Patagonia. Food Microbiol 28:503-509

Saini JK, Saini R, Tewari L (2015) Lignocellulosic agriculture wastes as biomass feedstocks for second-generation bioethanol production: concepts and recent developments. 3 Biotech 5:337-353

Sankh S, Thiru M, Saran S, Rangaswamy V (2013) Biodiesel production from a newly isolated Pichia kudriavzevii strain. Fuel 106:690-696

Saucedo-Luna J, Castro-Montoya AJ, Martinez-Pacheco MM, SosaAguirre CR, Campos-Garcia J (2011) Efficient chemical and enzymatic saccharification of the lignocellulosic residue from Agave tequilana bagasse to produce ethanol by Pichia caribbica. J Ind Microbiol Biotechnol 38:725-732

Singhal N, Kumar M, Kanaujia PK, Virdi JS (2015) MALDI-TOF mass spectrometry: an emerging technology for microbial identification and diagnosis. Front Microbiol 6:791

Talukder AA, Easmin F, Mahmud SA, Yamada M (2016) Thermotolerant yeasts capable of producing bioethanol: isolation from nutural fermented sources, identification and characterization. Biotechnol Biotechnol Equip 30:1106-1114

Tamura K, Stecher G, Peterson D, Filipski A, Kumar S (2013) MEGA6: molecular evolutionary genetics analysis version 6.0. Mol Biol Evol 30:2725-2729

Tani A, Sahin N, Fujitani Y, Kato A, Sato K, Kimbara K (2015) Methylobacterium species promoting rice and barley growth and interaction specificity revealed with whole-cell matrix-assisted laser desorption/ionization-time-of-flight mass spectrometry (MALDITOF/MS) analysis. PLoS One 10:e0129509

Techaparin A, Thanonkeo P, Klanrit P (2017) High-temperature ethanol production using thermotolerant yeast newly isolated from Greater Mekong Subregion. Braz J Microbiol 48:461-475

Toivari M, Vehkomäki MLL, Nygård Y, Penttilä M, Ruohonen L, Wiebe MG (2013) Low pH D-xylonate production with Pichia kudriavzevii. Bioresour Technol 133:555-562

Tolieng V, Kunthiphun S, Savarajara A, Tanasupawat S (2018) Diversity of yeasts and their ethanol production at high temperature. J Appl Pharm Sci 8:136-142

White TJ, Bruns TD, Lee SB, Taylor JW (1990) Amplification and direct sequencing of fungal ribosomal RNA genes for phylogenetics. In: Innis MA, Gelfand DH, Sninsky JJ, White TJ (eds) PCR protocols: a guide to methods and applications. Academic Press, San Diego, pp 315-322

Yuangsaard N, Yongmanitchai W, Yamada M, Limtong S (2013) Selection and characterization of a newly isolated thermotolerant Pichia kudriavzevii strain for ethanol production at high temperature from cassava starch hydrolysate. Anton van Leeuwenhoek 103: $577-588$

Zhang Q, Huo N, Wang Y, Zhang Y, Wang R, Hou H (2017) Aromaenhancing role of Pichia manshurica isolated from Daqu in the brewing of Shanxi Aged vinegar. Int J Food Prop 20:2169-2179

Zoecklien B, Fugelsang K, Gump B, Nury F (1995) Wine analysis and production. Chapman \& Hall, New York

Publisher's note Springer Nature remains neutral with regard to jurisdictional claims in published maps and institutional affiliations. 